\title{
REACTIVITY INSERTION ACCIDENT ANALYSIS OF KARTINI REACTOR
}

\author{
Tegas Sutondo \\ Staff of the Center for Technology of Accelerator and Material Process, BATAN, Yogyakarta \\ e-mail : ptapb@batan.go.id
}

Received 12 April 2011, received in revised form 3 Mei 2011, accepted 4 Juni 2011

\begin{abstract}
REACTIVITY INSERTION ACCIDENT ANALYSIS OF KARTINI REACTOR. A transient analysis of reactivity insertion accident of Kartini reactor during start up from the minimum critical condition has been performed to estimate the effect on the fuel temperature increase. Two cases of reactivity insertion limits had been assumed in this study i.e. the reactivity insertions were limited by the actuation of overpower trip system (110\%) for the $1^{\text {st }}$ case and by manual scram when the control rod reached the $100 \%$ UP position, assuming the overpower trip system was failed to function for the $2^{\text {nd }}$ case. Adiabatic condition was assumed in this study, to get the most severe condition. The result shows that based on the assumed power level of trip setting for the $1^{\text {st }}$ case, the total reactivity insertion was $0.82 \$$, corresponding to the reactor period of about $2 s$ and causing the maximum fuel temperature increase of around $11^{\circ} \mathrm{C}$ or the maximum fuel temperature of $45^{\circ} \mathrm{C}$. For the $2^{\text {nd }}$ case the total reactivity insertion at the trip point was $1.367 \$$, resulting in the maximum fuel temperature increase of about $103^{\circ} \mathrm{C}$ or maximum fuel temperatur of around $137^{\circ} \mathrm{C}$ which is still far below the defined design limit of $1115^{\circ} \mathrm{C}$ for transient condition and $700^{\circ} \mathrm{C}$ for steady state as well. This result concludes that by limiting the available core excess of reactivity at reasonably low, it could prevent the fuel from possible of undergoing an excessive temperature increase, during the postulated reactivity insertion accident.
\end{abstract}

Keywords: Transient analysis, reactivity insertion, accident, reactor kartini, fuel temperature.

\begin{abstract}
ABSTRAK
ANALISIS KECELAKAAN PENYISIPAN REAKTIVITAS PADA REAKTOR KARTINI. Telah dilakukan analisis transient kecelakaan penyisipan reaktivitas pada reaktor Kartini saat start up dari kondisi kritis minimum, untuk memperkirakan pengaruhnya terhadap kenaikan suhu maksimum dari bahan bakar. Dalam kasus ini diasumsikan 2 batas penyisipan reaktivitas yaitu untuk kasus pertama, penyisipan reaktivitas dibatasi oleh reaktor scram akibat aktuasi sistem trip level daya ketika tingkat daya reaktor mencapai batas setting yang ditetapkan (110\%), sedang untuk skenario kedua diasumsikan bahwa sistem trip level daya tidak berfungsi, sehingga reaktor dimatikan secara manual ketika batang kendali telah mencapai posisi UP (100\%). Untuk mendapatkan kondisi yang memberikan dampak terparah maka diasumsikan kondisi adiabatik. Hasil analisis menunjukkan bahwa berdasarkan setting tingkat daya pada sistem trip pada kasus pertama maka diperoleh total penyisipan reaktivitas sebesar 0,82 \$ yang sesuai dengan periode reaktor sekitar $2 \mathrm{~s}$, dan hal ini menyebabkan kenaikan suhu bahan bakar maksimum sekitar $11^{\circ} \mathrm{C}$. Untuk kasus kedua total penyisipan reaktivitasa ketika reaktor scram sebesar 1,367 , yang memberikan kenaikan suhu teras rerata sebesar $103{ }^{\circ} \mathrm{C}$ atau suhu maksimum bahan bakar sekitar $137^{\circ} \mathrm{C}$ yang masih jauh di bawah batas disain untuk kondisi transient sekitar $1115^{\circ} \mathrm{C}$ maupun untuk kondisi tunak sekitar $700^{\circ} \mathrm{C}$. Disimpulkan bahwa dengan membatasi muatan bahan bakar atau reaktivitas lebih teras pada level yang cukup rendah, maka hal tersebut dapat mencegah kemungkinan terjadinya kenaikan suhu bahan bakar yang berlebihan saat terjadi kecelakaan penyisipan reaktivitas yang dipostulasikan.
\end{abstract}

Kata kunci: Analisis transient, kecelakaan, penyisipan reaktivitas, reaktor kartini, suhu bahan bakar

\section{INTRODUCTION}

Kartini reactor is one of three research reactors in Indonesia having been operated since March 1979, and has undergone several times of fuel substitution and reshuffling. With the increase of fuel burn up and the changes in core configuration, it is necessary to reevaluate some safety related parameters as to assure the compliance with the defined operational limit conditions ${ }^{(1,2)}$. This paper is part of the safety evaluation works of Kartini reactor being performed aimed at updating the content of safety analyses report (SAR) document. One of important cases needs to be evaluated is the maximum fuel temperature under transient conditions following the 
postulated reactivity insertion accident to ensure the integrity of fuel clad. Such a case of accident has never been performed previously.

In this analysis the reactivity insertion accident was simulated by assuming the malfunction of the control rod's driving system, occurred during rod worth calibration work of the most reactive rod, where the rod button was assumed to be stuck, while being pressed down from its minimum critical condition, with the other rods were in full out position. In this case it was assumed also that the reactor period trip system, limiting the reactivity insertion rate was failed to function, causing the rod to continue moving up until the action of the following two scenarios were in effect:

1. For the $1^{\text {st }}$ case, the power excursion was stopped by the actuation of the overpower trip system, causing reactor to scram with all of the rods dropped promptly into the core when the power level reached the setting point i.e. $110 \%$ of the nominal power.

2. For the $2^{\text {nd }}$ case, the overpower trip system was assumed to be failed to function, and the power excursion was stopped by manual scram when the rod reached $100 \%$ up position.

In order to get the most severe condition, an adiabatic approach had been assumed, resulted in the accumulation of heat in the fuel meat. Further the point reactor kinetic equation was used as the basis of the analysis and the analytical approach was used to solve the equations representing the two conditions.

\section{Theoretical Background}

Any rod withdrawal from a stable or critical condition would result in the increase of core reactivity that would then be used to increase the reactor power level to a higher, stable condition. The increase of power level would then result in the increase of the fuel temperature, which is proportional to the total energy generated and the heat capacity of the fuels in the core. In case of adiabatic condition, the total energy generated can be represented by the following equation:

$$
E(t)=\int_{t} P(t) d \mathrm{t}=C \cdot \Delta \mathrm{T}
$$

with

$E(t) \quad=$ energy generated during the time span of $t$ (watt-s)

$P(t) \quad=$ reactor power as a function of time (watt)

$\Delta T \quad=$ fuel temperature increase $\left({ }^{\circ} \mathrm{C}\right)$

$\mathrm{C}=$ Heat capacity of all fuels loaded in the core (watt-s $\left./{ }^{\circ} \mathrm{C}\right)$

Based on the point kinetics equation, the general form of power excursion following the insertion of reactivity $\rho$ from a critical condition can be represented as follows ${ }^{(3,4)}$.

$$
P(t)=\mathrm{P}_{0}\left[\frac{\beta}{\beta-\rho} \mathrm{e}^{\mathrm{t} / \mathrm{T} 1}-\frac{\rho}{\beta-\rho} e^{-t / T 2}\right]
$$

where $\mathrm{T} 1$ and $\mathrm{T} 2$ = reactor period which can be represented as:

$$
\mathrm{T} 1=\frac{\beta-\rho}{\lambda(\rho+\gamma)} ; \quad \mathrm{T} 2=\frac{l}{\beta-\rho}
$$

$P(t) \quad=$ reactor power (watt) as a function of time $t$

$P_{0} \quad=$ initial power level (watt)

$\beta=\beta_{\text {eff }}=$ effective delayed neutron fraction

$\rho=\quad=$ reactivity as a function of time

$l \quad=$ prompt neutron life time (s)

$t \quad=$ time of insertion (s)

$\gamma \quad=$ rate of reactivity insertion $(\mathrm{d} \rho / \mathrm{dt}<\beta)$ 
$1=$ decay constant of the delayed neutron precursors $(1 / \mathrm{s})$

The reactivity insertion of the two accident scenarios being studied can be represented by three different models as follows.

1. Positive ramp reactivity insertion with total reactivity $\rho<1 \$$

2. Positive ramp reactivity insertion with total reactivity $\rho>1 \$$

3. Negative step reactivity when reactor trip with total trip reactivity $|\rho|>1 \$$

For the first case, where the rod movement was stopped by the overpower trip system, the total reactivity inserted $(\rho)$ will be less than $1 \$$ and hence the $2^{\text {nd }}$ term of equation (2) can be neglected, resulted in the simplified equation as follows:

$$
P(t)=\mathrm{P}_{0} \frac{\beta}{\beta-\rho} \mathrm{e}^{\mathrm{t} / \mathrm{T} 1}
$$

Equation (4) can also be used for the condition after reactor trip, with a negative step reactivity insertion (| $\rho$ $\mid>1 \$)$. The reactor period for this case becomes

$$
\mathrm{T} 1=\frac{\beta-\rho}{(\lambda \rho)}
$$

In this study, the insertion rate $y$ was assumed to be constant which was taken as the average of insertion rate of the rod being used, and hence the associated reactivity inserted as a function of time of withdrawal in this case will be $\rho(t)=\gamma . t$

For the second case, where the control rod moves up until the $100 \%$ out position, the total reactivity inserted will be equal to the core excess of reactivity available, which in this case $\rho>1 \$$. Hence, the effect of delayed neutron fraction ( $\beta$ ) can be neglected meaning the $1^{\text {st }}$ term of equation (3) can be wiped out. The power excursion for this case can then be represented by in the following equation

$$
P(t)=\mathrm{P}_{0} \mathrm{e}^{\mathrm{t} / \mathrm{T} 2}
$$

in which $\mathrm{T} 2=/ / \Delta \rho_{\mathrm{p}}$, and $\Delta \rho_{\mathrm{p}}=\rho-\beta=$ prompt reactivity.

Since the prompt neutron lifetime $I$ is so short $\left(\sim 10^{-5} \mathrm{~s}\right)$, the reactor power will then increase very quickly, followed by the increase of fuel temperature, resulting in the negative feedback reactivity, which will then restrict the power excursion to a new equilibrium state. For the case of adiabatic condition, where the heat generated remains accumulated in the fuel, the "Fuchs - Hansen" model will be well applicable to estimate the total energy generated during transient, following the reactivity insertion $(\rho) .^{(3,4)}$ Equation (7) represents the relationship of the energy balance with the reactivity insertion fort his model.

$$
\mathrm{E}=\frac{2 \mathrm{C} \cdot \Delta \rho_{p}}{\alpha}
$$

with $\alpha=$ negative fuel temperature coefficient $\left(\mathrm{dk} / \mathrm{k}^{\circ} \mathrm{C}\right)$. follow:

Referring to equation (1) and (7) the average increase of core temperature $(\Delta T)$ can then be determined as

$$
\Delta \mathrm{T}=\mathrm{E} / \mathrm{C}=\frac{2 \Delta \rho_{p}}{\alpha}
$$

and the maximum power associated with the reactivity insertion will be:

$$
P_{\max }=\frac{C \Delta \rho_{p}^{2}}{2 \alpha l}
$$

\section{Core and Control Rods Descriptions}


Kartini reactor is a typical design of TRIGA Mark II $250 \mathrm{~kW}$ which is then operated at reduced nominal power of $100 \mathrm{~kW}$ with 69 fuel elements distributed within ring B to ring F. Some graphite elements are placed at the outermost ring (ring F) to improve the core reactivity. Three control rods (B4C) are used to control the operation i.e. safety and shim rods occupied ring $\mathrm{C} 5$ and $\mathrm{C} 9$ respectively, and regulating rod placed at ring E1. Figure 1 presents the typical core pattern of Kartini reactor.

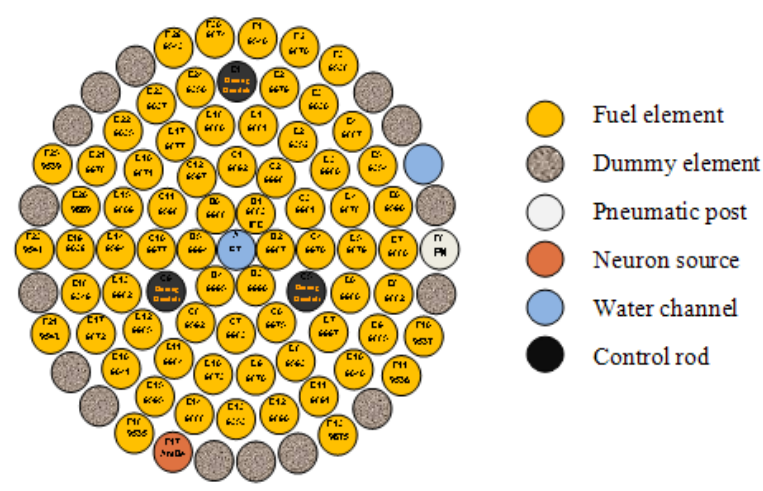

Figure 1. Typical core pattern of Kartini reactor

\section{METHODOLOGY}

The following described briefly several steps of work performed in this study.

1. Reactivity calibration to evaluate the reactivity of the 3 control rods and the associated core excess of reactivity available for the latest core configuration. The result can then be used to define the control rod to be used for the basis of analysis (i.e. the most reactive one) and the associated average reactivity insertion rate.

2. Determination the reactivity insertion and the associated power level as a function of time of withdrawal, based on the available kinetic parameters and the heat capacity of the standard TRIGA fuel, as presented in Table 1 below. The reactivity insertion limit, and the trip reactivity available for the two cases can then be determined based on the assumed scenarios.

3. Determination of the energy generated during the transient and the associated core average temperature increase for the two cases. The maximum fuel temperature can then be determined by applying the assumed power peaking factor of $2.38^{(1)}$ and the intitial temperature.

Table1. Kinetic parameters and the heat capacity of the standard TRIGA fuel ${ }^{(4)}$

\begin{tabular}{|l|c|}
\hline \multicolumn{1}{|c|}{ Parameter } & Value \\
\hline Reactor Kinetics Parameters & 0.077 \\
\hline Decay constant: $\lambda\left(\mathrm{s}^{-1}\right)$ & 0.007 \\
\hline Effective delayed neutron fraction: $\beta$ & $4.00 \mathrm{E}-05$ \\
\hline Prompt neutron life time: I $(\mathrm{s})$ & $1.200 \mathrm{E}-04$ \\
\hline Negative temperature reactivity coefficient: $\alpha\left(\mathrm{dk} / \mathrm{k}{ }^{\circ} \mathrm{C}\right)$ & $6.00 \mathrm{E}-05$ \\
\hline Average prompt neutron life time: $/(\mathrm{s})$ & \\
\hline Heat Capacity: $\mathrm{C}_{p}$ & $2.18 ; \mathrm{T}=34{ }^{\circ} \mathrm{C}$ \\
\hline $\mathrm{C}_{P}$ volumetric $=2,04+4,17 \times 10^{-3} \mathrm{~T}\left(\mathrm{~W}-\mathrm{sec} / \mathrm{cm} 3^{\circ} \mathrm{C}\right)$ & $8.363 \mathrm{E}+02$ \\
\hline $\mathrm{T}=$ fuel temperature $\left({ }^{\circ} \mathrm{C}\right):$ & $5.771 \mathrm{E}+04$ \\
\hline$C_{P}$ for each fuel $\left(\right.$ vol $\left.=383,32 \mathrm{~cm}^{3}\right)\left(\mathrm{W}-\mathrm{sec} /{ }^{\circ} \mathrm{C}\right)$, & \\
\hline$C_{P}$ for the whole of core $: 69$ fuels $\left(\mathrm{W}-\mathrm{sec} /{ }^{\circ} \mathrm{C}\right)$ & \\
\hline
\end{tabular}




\section{RESULTS AND DISCUSSION}

Table 2 presents the result of reactivity measurement of the 3 control rods for the latest core condition, and the associated core excess reactivity. The rod at C-9 (shim rod) seen to be the most reactive one, with total reactivity of $3.067 \$$, which was then taken as the basis for this study. Figure 2 shows the integral reactivity profile of this rod. Based on the specified rod withdrawal speed and the core height, the average reactivity insertion rate of this rod can then be determined i.e. $\gamma=0.051 \$ / \mathrm{s}$.

Tabel 2. Control rod reactivity and core excess of Kartini reactor

\begin{tabular}{|l|c|c|}
\hline \multicolumn{1}{|c|}{ Control Rod } & Location & Reactivity (\$) \\
\hline Shim rod & Ring C-9 & 3.067 \\
\hline Safety rod & Ring C-5 & 3.054 \\
\hline Regulating rod & Ring E-1 & 1.587 \\
\hline Total & 7.708 \\
\hline \multicolumn{2}{|l|}{ Core excess of reactivity } & 1.359 \\
\hline
\end{tabular}

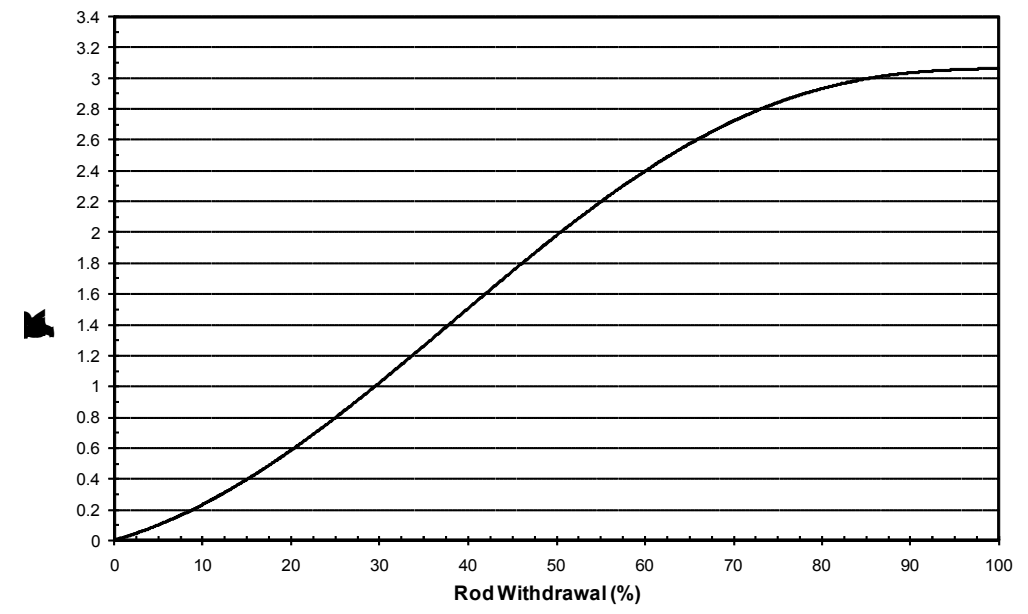

Figure 2. Integral reactivity of shim rod

For the first case, the overpower trip system was taken at $130 \mathrm{~kW}$, to take into account a $20 \%$ of the maximum tolerance of the reactor power calibration accuracy. Based on this power limit the reactivity insertion and the associated power level as a function of time can be determined. Figure 3 shows the reactor period and the power excursion and the coast down during the transient before. 


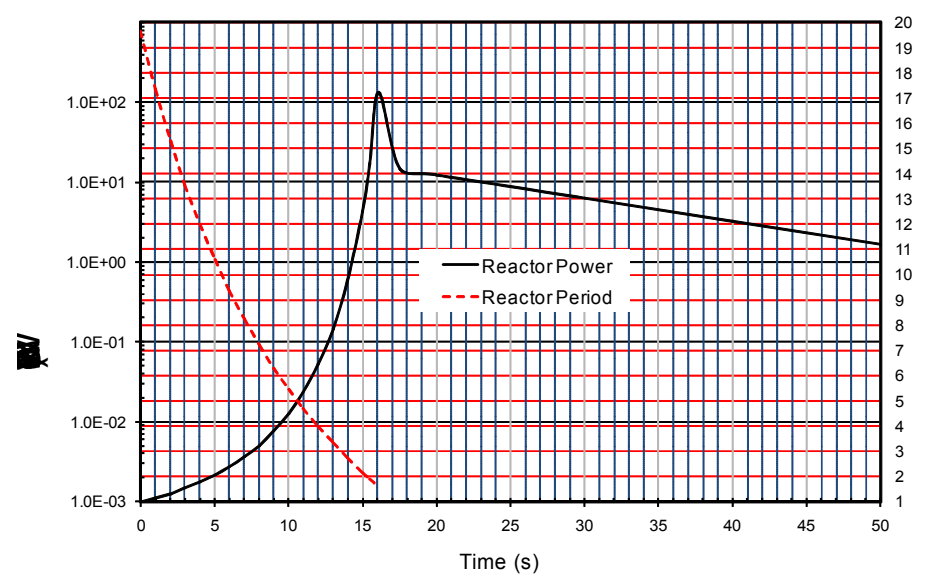

Figure 3. Power excursion and coast down following reactor trip

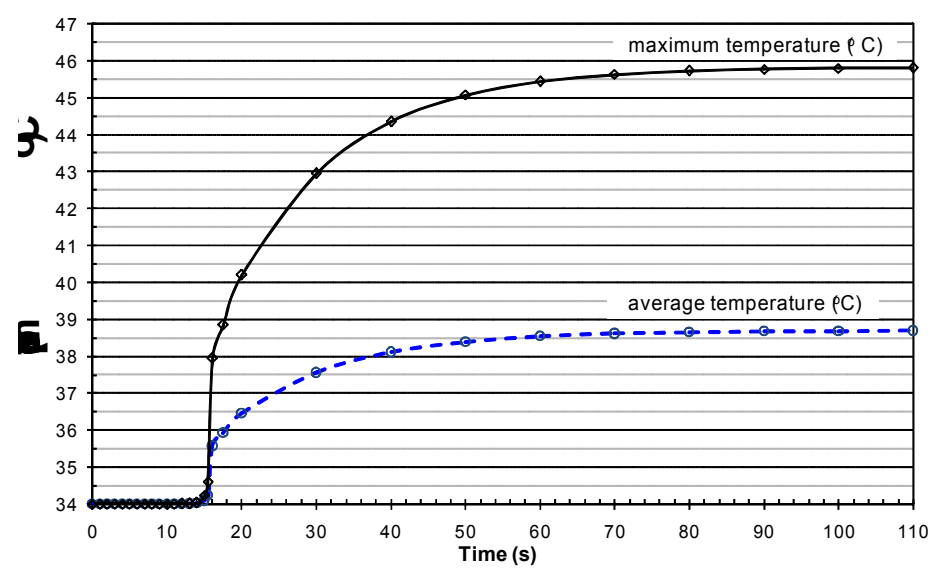

Figure 4. Core average and maximum temperatures during transient

The result indicates that the minimum reactor period at the trip point seen to be about 2 seconds, which is less than the defined setting trip period of 7 seconds. However the energy generated during transient was still very low, causing not so significant of core temperature increase, i.e. about $5^{\circ} \mathrm{C}$ in average or maximum of $11^{\circ} \mathrm{C}$ or maximum fuel temperature of around $45^{\circ} \mathrm{C}$ (assuming initial temperature of $34{ }^{\circ} \mathrm{C}$ ). This justify that the defined setting value for the period trip system is conservative enough to limit the power excursion before reaching the defined value of $110 \%$ overpower trip setting. Figure 4 shows the fuel average and maximum temperature profile during transient. The result indicate also that from the fuel temperature limit point of view, the setting point for overpower trip system is conservative enough to protect the fuel integrity due to such transient event.

Tablel 3. Summary of the results

\begin{tabular}{|l|c|c|}
\hline \multirow{2}{*}{ PARAMETER } & \multicolumn{2}{c|}{ Value } \\
\cline { 2 - 3 } & $1^{\text {st }}$ Case & $2^{\text {nd }}$ Case \\
\hline Initial reactor power (watt) & 1 & 1 \\
\hline Initial rod position (\%) & 44 & 44 \\
\hline Duration of reactivity insertion (s) & 16,09 & 33,8 \\
\hline Change of core reactivity (s) (\$) & 0,818 & 1,367 \\
\hline Maximum rod position (\%) & 70.67 & 100 \\
\hline
\end{tabular}




\begin{tabular}{|l|c|c|}
\hline Total rod reactivity inserted $(\$)$ & 1.049 & 3.054 \\
\hline Trip reactivity $(\$)$ & 7.159 & 7.708 \\
\hline Total energy generated $(\mathrm{kWs})$ & 270.78 & 2491 \\
\hline Maximum transient power $(\mathrm{MW})$ & 0.130 & 26.88 \\
\hline Average core temperature increase $\left({ }^{\circ} \mathrm{C}\right)$ & 4.69 & 43.2 \\
\hline Maximum core temperature increase $\left({ }^{\circ} \mathrm{C}\right)$ & 11.2 & 102.7 \\
\hline Maximum fuel temperature $\left({ }^{\circ} \mathrm{C}\right)$ & 45.2 & 136.7 \\
\hline
\end{tabular}

For the second case, where the rod moved up until full position (100\%), the total reactivity inserted in this case was about $1.367 \$$ which represents the amount of core excess of reactivity available. The total energy generated for this insertion was 2,491 MWs with the peak power of about $26.88 \mathrm{MW}$. This would result in the increase of core average temperature by $43,2{ }^{\circ} \mathrm{C}$ or maximum increase of $102.7^{\circ} \mathrm{C}$. By assuming the initial temperature of $34{ }^{\circ} \mathrm{C}$ or the maximum fuel temperature would be of $136.7^{\circ} \mathrm{C}$. This value is still far below the defined design limit of temperature for both transient and steady state conditions, which is around $1150{ }^{\circ} \mathrm{C}$ and $700^{\circ} \mathrm{C}$ respectively. This result justify that with the available core excess of reactivity of $1.367 \$$, would not result in the excessive increase of fuel temperature. Table 3 summarizes the result of the two cases.

\section{CONCLUSION}

A transient analysis of reactivity insertion accident of Kartini reactor during start up from the minimum critical condition has been performed to estimate the effect on the fuel temperature increase. Two cases of reactivity insertion limits was assumed in this study, i.e. for the $1^{\text {st }}$ case the reactivity insertions was limited by the actuation of overpower trip system whilst for the $2^{\text {nd }}$ case it was limited by manual scram when the rod reached $100 \%$ of withdrawal position. The result shows that based on the assumed power level trip setting for the $1^{\text {st }}$ case, the maximum reactivity inserted was $0.82 \$$, corresponding to the reactor period of about $2 \mathrm{~s}$, and causing the maximum fuel temperature increase of around $11^{\circ} \mathrm{C}$. The reactor period at this point was about $2 \mathrm{~s}$, which was below the defined minimum reactor period's trip setting of $7 \mathrm{~s}$. The result justifies that the defined minimum limit of reactor period's trip setting was conservative enough to prevent the reactor from further more serious condition. For the $2^{\text {nd }}$ case the total reactivity insertion at the trip point was $1.367 \$$ which represents the available core excess of reactivity, and this resulted in the maximum fuel temperature increase of about $103{ }^{\circ} \mathrm{C}$ or maximum fuel temperature of around $137{ }^{\circ} \mathrm{C}$ which was still far below the defined design limit value. This result concludes that by limiting the available core excess of reactivity at reasonably low could prevent the fuel from possible of undergoing an excessive temperature increase, during the postulated reactivity insertion accident.

\section{REFERENCES}

1. ROBERT S. DAUM, SAURIN MAJUMDAR, YUNG LIU AND MICHAEL C. BILLONE, Journal of Nuclear Science and Technology, Vol. 43, (2006) 1054.

2. SAFETY REPORTS SERIES No. 55, Safety analysis for research reactors. - Vienna: International Atomic Energy Agency (2008).

3. ANDRAŽ PETROVIĆ, MATJAŽ RAVNIK, Physical Model of Reactor Pulse, International Conference Nuclear Energy for New Europe (2004).

4. IAEA, TRIGA Characteristics, December 2004, http://www.ansn.iaea.org/Common/documents/Training/ TRIGA\%20Reaktors\%20. 